\title{
The Potentials of Rhodes Grass (Chloris Gayana Kunth) as Drought Resistant Perennial Forage Grass in Nigeria
}

\author{
Y Na Allah ${ }^{1}$ and A Bello ${ }^{2 *}$ \\ ${ }^{1}$ Department of Animal Science, Usmanu Danfodiyo University, Nigeria \\ ${ }^{2}$ Department of Veterinary Anatomy, Usmanu Danfodiyo University, Nigeria
}

*Corresponding author: Y Na Allah, Department of Animal Science, Usmanu Danfodiyo University, Sokoto, Nigeria.

To Cite This Article: Y Na Allah, A Bello, The Potentials of Rhodes Grass (Chloris Gayana Kunth) as Drought Resistant Perennial Forage Grass in Nigeria. Am J Biomed Sci \& Res. 2019 - 6(3). AJBSR.MS.ID.001025. DOI: 10.34297/AJBSR.2019.06.001025.

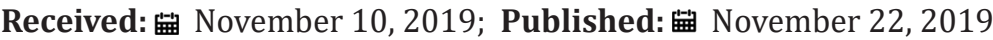

\begin{abstract}
Rhodes grass (Chloris gayana Kunth) being one of the improved pasture species in Nigeria has been increasingly cultivated over the last few years in the country due to its high dry matter yield, favourable economics of cultivation, and superiority over other perennial forage grasses. Base on this fact, there is need to understand fully the potentials of the plant. The major objective of this paper is to evaluate the potentials of Rhode grass (Chloris gayana Kunth) in Nigeria..
\end{abstract}

Keywords: Chloris gayana Kunth; Drought Resistant Perennial Forage Grasses; Nigeria

\section{Introduction}

Rhodes grass, abyssinian Rhodes grass, Callide Rhodes grass, common Rhodes grass [English]; chloris, herbe de Rhodes [French]; capim de Rhodes [Portuguese]; grama de Rodas, pasto de Rodas, pasto Rhodes, zacate gordura [Spanish]; rhodesgras [Afrikaans]; koro-korosan [Philippines/Tagalog]. Rhodes grass is a perennial or annual tropical grass. It is a leafy grass, 1-2 $\mathrm{m}$ in height, highly variable in habit. The culms are tufted or creeping, erect or decumbent, sometimes rooting from the nodes. The roots are very deep, down to $4.5 \mathrm{~m}$. The leaves are linear, with flat or folded glabrous blades, $12-50 \mathrm{~cm}$ long $\times 10-20 \mathrm{~mm}$ wide, tapering at the apex. The seed head has an open hand shape and encompasses 2-10 one-sided or double-sided racemes, 4-15 cm long. The inflorescences are light greenish brown (rarely yellow) in colour and turn darker brown as they mature [1]. The spikelets (over 32) are densely imbricated and have two awns. The fruit is a caryopsis, longitudinally grooved [1-5].

The low nutritive quality of the forage during the growth period is mainly due to environmental stresses such as high temperatures [6], infertile soils [7] and poor management [8]. In recent years, there has been several attempts to improve the nutritive quality of the forage resources through propagation of improved species with high nutritive value [9], which requires establishment of suitable sown pasture and feed lots to meet the higher nutritional needs of more productive animals [10].
Rhodes grass (Chloris gayana Kunth) being one of the improved pasture species in Nigeria has been increasingly cultivated over the last few years in the country due to its high dry matter yield, favourable economics of cultivation, and superiority over other perennial forage grasses [11]

In order to improve the availability of good quality pasture feed, a fast growing, high yielding and qualitative forage species are required for the development of sown pastures (via pasture agronomy) that are to be sustained under intensive systems of management. Intensive pasture production make use of forage species that prove their superiority in terms of bulk productivity (dry matter yield per unit area), palatability, chemical composition, nutrient availability, persistence under defoliation regimes and inclement climatic conditions, competition and compatibility with other forages in the pasture ecosystem (Muhammad and Abubakar, 2004). Therefore there is need to evaluate the growth and herbage yield of the newly introduced pasture species such as Rhode grass (Chloris gayana Kunth) while subjecting it to some management practices for optimum growth, yield and nutritive value to increase the availability of good quality feed for improved livestock production.

According to Muhammad and Abubakar (2004) [12] increments in pasture feed production can be achieved by expansion of land 
areas under natural pastures or by increasing yields per unit land area through intensive production of improved pasture species. With the present trend of competitive land use in Nigeria, increasing pasture feed production through expansion of land area under natural pasture is hardly feasible as a result of the demographic changes. The only viable option therefore remains the production of improved species of grasses and legumes for intensive livestock production due to their high forage yield and nutritive value [1314].

More so, pasture management techniques such as fertilization and spacing are utilized in order to secure a desirable balance for high productivity $[15,16]$. Therefore, evaluation of growth and herbage yield of Rhodes grass (Chloris gayana Kunth) as affected by nitrogen fertilizer and inter row spacing in Sokoto sound justifiable. The major objective of this paper is to evaluate the potentials of Rhode grass (Chloris gayana Kunth) in Nigeria.

\section{Origin and Distribution}

Chloris gayana is a native of South Africa and was named Rhodes after the famous Cecil Rhodes, who popularized it [17]. Rhodes grass is now widespread in tropical and subtropical areas worldwide. It was introduced into India, Pakistan, Australia and the USA. In Australia, it was introduced by soldiers returning from the Boer wars at the beginning of the 20th century. In Western Australia, Rhodes grass has become one of the most widely sown subtropical grasses since year 2000 [4]. The species was introduced in India through USA and later in Karnataka in 1920. Being drought resistant, Rhodes grass is found in semi-arid region and other lowlying areas [17].

\section{Botany}

Rhodes grass is a perennial or annual tropical grass. It is a leafy grass, $1-2 \mathrm{~m}$ in height, highly variable in habit. The culms are tufted or creeping, erect or decumbent, sometimes rooting from the nodes. The roots are very deep, down to $4.5 \mathrm{~m}$. The leaves are linear, with flat or folded smooth blades, $12-50 \mathrm{~cm}$ long x $10-20 \mathrm{~mm}$ wide, tapering at the apex. The seed head has an open hand shape and encompasses 2-10 one-sided or double-sided racemes, $4-15 \mathrm{~cm}$ long. The inflorescences are light greenish brown (rarely yellow) in colour and turn darker brown as they mature [1]. The spikelets (over 32) are densely arranged in an overlapping manner and have two awns. The fruit is a caryopsis, longitudinally grooved [1-5]. It has a straw coloured on ripening. It produces profuse amount of seeds. Seed count 7250000 to $9500000 / \mathrm{kg}$ [17].

\section{Adaptation}

Rhodes grass is a spring and summer-growing grass found in open woodlands and grasslands, in road margins, disturbed sites and riverbanks. It is cultivated as sown pastures in irrigated terraces $[1,3]$. Chloris gayana thrives in places where annual temperatures range from $16.5^{\circ} \mathrm{C}$ to above $26^{\circ} \mathrm{C}$, with maximum growth at $30^{\circ} \mathrm{C} / 25^{\circ} \mathrm{C}$ (day/night temperature). Optimal annual rainfall is about $600-750 \mathrm{~mm}$ with a summer-rainfall period $[1,4,18]$. Rhodes grass can survive in areas where annual rainfall ranges between $310 \mathrm{~mm}$ and $4030 \mathrm{~mm}$ and where temperature extremes are $5^{\circ} \mathrm{C}$ and $50^{\circ} \mathrm{C}[1,5]$. Due to its deep roots, Rhodes grass can withstand long dry periods (over 6 months) and up to 15 days of flooding $[1,2]$. Seasonal water logging over $30 \mathrm{~cm}$ kills the plant [2]. Rhodes grass grows on a wide range of soils from poor sandy soils to heavy clayey alkaline and saline soils (more than $10 \mathrm{dS} / \mathrm{m}$ ). This salt tolerance is particularly valuable in irrigated pastures where it can be cultivated without problem. Rhodes grass does better on fertile, well-structured soils and it prefers soil pH between 5.5 and 7.5. Establishment on acidic soils is difficult. It is tolerant of Li but not of Mn and Mg [1]. Chloris gayana is a full sunlight species which does not grow well under shade $[1,2,18]$.

\section{Management Practices}

\section{Land preparation}

The land should be cleared from weeds and trees before ploughing [19]. The land should be ploughed two to three times to get a fine and leveled seedbed. As the Rhodes grass seed is very small it needs a well-prepared seedbed [20]. The seedbed should be ploughed and prepared well. A well-prepared seedbed favours seed germination, seedling emergence and growth [21].

\section{Planting time}

Planting should be done at the start of the main rainy season when the soil has received sufficient moisture to support germination and establishment. Seed germinates within 7 days after planting [1]. Sowing too deeply will result in failure or poor germination. Rhodes grass seed will germinate under slightly cooler conditions than most summer growing grasses [21]

\section{Seed rate and planting methods}

Rhodes grass can be established vegetatively (root splits) or from seed. Seed rate varies depending on seed quality (germination and purity), sowing method, environmental conditions and land preparation. Generally, the seed rate should be from 3 - 15kgha 1 considering the previous factors. High seed rate is usually important in cooler and high-altitude areas. Seed should be sown on the surface no deeper than $2 \mathrm{~cm}$ [1]. Rhodes grass can be row sown or broadcasted. For broadcasting seed can be mixed with soil or sand. After sowing it should be covered with light soil by using tree branches. Alternatively, sowing the seed and light packing by driving animals before and after sowing is also another option. However, if the labour is available, it can be planted in rows. In this case, the spacing between rows should be $20 \mathrm{~cm}$ [22]. Planting should be conducted when the soil gets moist and care has to be taken to uniformly apply/drill the seeds over the prepared land [21]. 


\section{Fertilizer application}

Rhodes grass is productive in moderate to high fertile soils. If the soil is infertile, applying nutrients to the soil is essential. Applying nitrogen and phosphorus fertilizers is recommended. Applying DAP fertilizer at the rate of $100 \mathrm{kgha}^{-1}$ at planting and urea at the rate of $50 \mathrm{kgha}^{-1}$ after establishment and at every cut is essential. Some literatures recommend applying $100 \mathrm{kgha}-1$ nitrogen after each cut. If available, applying manure is another option. Manure can be applied at the rate of 5 - 10 tonsha $^{-1}$ [19]. In general, grasses have a high requirement for $\mathrm{N}, \mathrm{P}$ and $\mathrm{K}$. These nutrients should be applied after each cut or grazing. Generally, it is recommended that annual maintenance nutrient requirements for $\mathrm{N}, \mathrm{P}$ and $\mathrm{K}$ is $50-300 \mathrm{kgha}^{-1}, 10-20 \mathrm{kgha}^{-1}$ and $25-50 \mathrm{kgha}^{-1}$, respectively [19]. In addition to biomass improvement, fertilizer application enhances both nutritive value and yield. Rhodes grass gives an increased response to phosphorus in some areas and usually a spectacular linear response to nitrogen in the presence of adequate phosphorus and potassium, both in yield and in crude protein content. Split applications after each cut or after grazing cycles are better than one basic application with the usual rate of 275 to $400 \mathrm{kgha}^{-1}$. Generally, cut and carry system requires more maintenance inputs than the grazing system. If sown pastures are well-utilized and maintained with fertilizers, they will continue to provide high herbage yield for up to five years and start to decline thereafter. The usual productive life of Rhodes grass is three years; this can be extended by optimum fertilization [21].

\section{Weed, insect pest and disease control}

The newly established pasture should be free from weeds. Removing weeds by hand is essential thus, removing weeds reduces competition when the grass is weak, and it also minimizes the chances of further perpetuation of weeds by seed. Weed removal at early stage of Rhodes grass production is crucial as the plant is weak at this stage removing weeds makes establishment easier and enhances further survival. Weeding twice after planting at monthly intervals during establishment is recommended. Harvesting the grass and weeds together using sickle when there is vigorous growth is another alternative to control weeds. Using herbicide like 2-4-D is also effective to remove young broad-leaved weeds [22].

CASCAPE (2015) [21] reported that there are no insects observed on Rhodes grass but common pests such as armyworm may attack Rhodes grass pasture. There are no diseases observed on Rhodes grass production during CASCAPE project interventions in different districts of north-western Ethiopia. Diseases are more severe with legumes than with grasses.

\section{Harvesting, threshing and post-harvest handling}

To obtain high quantity and quality feed, the Rhodes grass should be harvested at 50\% flowering stage. Harvesting Rhodes grass at early stage will ensure higher levels of Crude Protein (CP) in the harvested material. As the harvesting time gets late the crude protein level of the grass gets low. The newly established pasture through seed sowing can be utilized within 3 - 5 months after sowing. The harvested material can be fed to livestock as fresh or it can be made hay for later feeding. If root split is used as a planting material, first harvest can be done from two to three months provided that there is adequate moisture and fertilizer application.

Rhodes grass makes good hay if it is cut at the beginning of flowering or a little earlier. Old stands give low quality hay. It is not suitable for silage making. When preparing hay appropriate hay making procedures should be followed. Rhodes grass can be grazed 4 - 6 months after planting. Highest production is attained in the second year. Rhodes grass is tolerant to heavy grazing and cutting, but production is reduced by very frequent defoliation. In the first year, depending on the soil and environmental conditions Rhodes grass can be harvested in October. After the first year it should be harvested anytime of the year when it reaches the optimum harvesting stage. In areas where frost occurs it should be harvested before the onset of frost. Studies show that cutting in every 28 days is better than cutting in every 14 days interval in irrigated conditions. It is better if cuttings are taken at monthly intervals. This depends on establishment year. It takes several months to harvest Rhodes grass pasture in the establishment year. After that year it can be harvested every month based on availability of rain (irrigation) and fertilizer (manure). If Rhodes grass is used for grazing, there should be care. Rhodes grass is very palatable to livestock. So, the pasture can be damaged by overgrazing. So, it is better to adopted cut and carry system when using Rhodes grass pasture. Digestibility and Crude Protein (CP) contents decline as the plant matures. So, for better utilization regular cutting and fertilization of the crop is necessary. Over mature Rhodes grass should be cut or burned. Burning is applicable in Rhodes grass as the grass is fire tolerant [21].

\section{Nitrogen Fertilizer and its Effect on Plant Growth and Yield}

High crop responses in terms of growth, tiller production, and tissue concentration of elements, and yield have been associated with application of nitrogen fertilizer [23]. The nutritive value of crops is also increased as a result of nitrogen fertilization. [24] reported that applied nitrogen $\left(0,84\right.$, and $\left.168 \mathrm{kgNha}^{-1}\right)$ in guinea grass increased dry matter yield of total herbage (5840, 8460 and $12400 \mathrm{kgha}^{-1}$ respectively) [25]. also reported increase in the dry matter yield of guinea grass with increasing nitrogen fertilizer application and recommended a dosage of $400 \mathrm{kgNha}^{-1}$ per year for guinea grass in Cuba. Application of nitrogen fertilizer was found to significantly increase the number of tillers per plant, total herbage yield of guinea grass grown in Nsukka, Nigeria [26,27]. Observed that the dry matter and crude protein yields on guinea grass sward depended largely on the level of $\mathrm{N}$ fertilizer applied. [28] reported that nitrogen fertilization increased the crude protein of Rhodes grass by $15 \%$ at the early stage of growth. 


\section{Effect of Nitrogen Fertilizer on Rhodes Grass (Chloris gayana) Production}

Fertilizer is the most important input that improves yield, growth and also the quality of annual forage plants. It has been observed that Rhodes grass responded well to nitrogen (N) fertilizer after a basic pre-plant phosphorous (P) application [2932]. Moreover, response of Rhodes grass was remarkable when nitrogen fertilizer was applied in a separate split dose [29,31,33,34]. Leaf area and leaf to stem ratio of Rhodes grass also increase by increasing nitrogen fertilizer [35]. Fertilizers treatment had a very significant effect on fodder yield both fresh and dry [35,36]. Thus, nitrogen and phosphorous fertilizers play very important role to enhance the fodder production both in quality and quantity of Rhodes grass [29].

\section{Effects of Spacing on Plant Growth and Yield}

It is always good to follow the recommended crop spacing guidelines since overcrowding of crops may reduce yields and it may also lower quality of the fruits produced because of competition for light and soil nutrients. If crops are planted too close to one another, it may be hard for the farmer to walk about in the garden weeding, spraying pesticides or doing crop inspection [37]. Appropriate spacing enables the farmer to keep appropriate plant population, avoid over and under population in a given plot of land which has negative effect on yield and quality [38]. Nadaf et al. (2005) reported that the grass species produced higher seed yield due to less interplant competition under wider $(100 \mathrm{~cm})$ than under narrow row $(50 \mathrm{~cm})$ spacing. Plant spacing of $25 \mathrm{~cm} \times 85 \mathrm{~cm}$ among $25 \mathrm{~cm} \times 85 \mathrm{~cm}, 50 \times 85 \mathrm{~cm}$ and $75 \times 85 \mathrm{~cm}$ spacings gave the highest fresh and dry matter yields of 25.54 and 11.28 tonsha $^{-1}$ respectively of Sorghum almum in an experiment conducted to assess the effect of plant spacing on yield and quality of Columbus grass (Sorghum almum) under rain fed at National Animal Production Research Institute Shika, Zaria [39,40]. Reported that the wider the inter row and intra row spacing of $75 \mathrm{~cm}$ and $100 \mathrm{~cm}$ respectively produced the highest dry matter yield with Vigna unguicuata L. var. 'Kanannado' in the semi-arid region of north western Nigeria, in a field trial to investigate the effects of inter and intra row spacing on the growth and fodder yield of cowpea (Vigna unguiculata L. Walp var. Kanannado).

\section{Growth and Herbage Yield of Rhodes Grass (Chloris gayana)}

$[41,42]$. Reported that data on growth performance of Rhode grass varies with type of cultivar, age of plant and other environmental factors. Rhodes grass stands up to the height of $90 \mathrm{~cm}$ [42]. The heights of Rhodes plant when measured reached $0.5-1.2 \mathrm{~m}(50-120 \mathrm{~cm})$ and fertile tillers measured $0.9-2.0 \mathrm{~m}(90$ to $200 \mathrm{~cm}$ ) tall. The foliage measures $25-50 \mathrm{~cm}$ long and $3-9 \mathrm{~mm}$ $(0.3$ to $0.9 \mathrm{~cm})$ wide $[41,43]$. Reported that height of Rhodes plants grown sole in the savannah region of Ethiopia at 8 weeks after sowing (8 WAS) varied from 100.7 to $121.0 \mathrm{~cm}$ tall. He also reported that number of leaves per plant (NL), leaf length (LL) and number of tillers per plant (NT) as $10-13$ leaves, $36.0-41.0 \mathrm{~cm}$ long and 81 tillers respectively [44]. However reported the growth parameters of Rhodes grass sown at Sokoto, a semi-arid region of Nigeria at 10 weeks after sowing (10 WAS) that plant height ( $\mathrm{PH})$, number of leaves per plant (NL), leaf length (LL), leaf width (LW) and number of tillers per plant (NT) as $76.04 \mathrm{~cm}$ tall, 6 leaves, $10.87 \mathrm{~cm}$ long, $1.23 \mathrm{~cm}$ wide and 79 tillers respectively.

Rhodes grass generally ranges from 7 - 25 tonsDMha-1 per year, depending on variety, soil fertility, environmental conditions and cutting frequency [1,2122]. Reported that on average, the herbage yield of Rhodes grass based on a study conducted on farmers' fields in the central highlands of Ethiopia was from 8.74 to 9.1 tons DMha ${ }^{1}$ per year on rain-fed conditions. Based on several studies, the dry matter yields of $[41,42,45]$ also reported that the herbage yield of Rhodes grass varies generally with type of cultivar, age of the plant and other environmental factors.

Table 1 above shows the reported values of herbage yield for Rhodes grass grown in different locations with the same ecological zones of Nigeria at different ages. The herbage yield values range from 4.1 to 14.3 tonDMha ${ }^{-1}$ under rain fed conditions and from 2.4 to 38.0tonsDMha ${ }^{-1}$ under irrigation. The herbage yields for the species grown in the dry Semi-arid savannah zone under the rain fed conditions range from 4.1 to 10.0 tonsDMha $^{-1}$.

Table 1: Herbage yields for Rhodes grass (Chloris gayana Kunth) at various locations in Nigeria.

\begin{tabular}{|c|c|c|}
\hline $\begin{array}{r}\text { Yields } \\
\left(\mathrm{KgDMha}^{-1}\right)\end{array}$ & Location & Source \\
\hline 6,000 (i) & $\begin{array}{c}\text { Dry Sudan Savannah, } \\
\text { Nigeria }\end{array}$ & Kallah \& Nzamane [54] \\
\hline 6,710 (at 100 days) $\mathrm{k}$ & Shika (NGS), Nigeria & Akinola \& Olorunju [45] \\
\hline $\begin{array}{c}11,820 \text { (at } 140 \\
\text { days) } \mathrm{k}\end{array}$ & Shika (NGS), Nigeria & Akinola \& Olorunju [45] \\
\hline $\begin{array}{c}10,130 \text { (at } 170 \\
\text { days) } \mathrm{k}\end{array}$ & Shika (NGS), Nigeria & Akinola \& Olorunju [45] \\
\hline 7,360 (at 100 days) s & Shika (NGS), Nigeria & Akinola \& Olorunju [45] \\
\hline $\begin{array}{c}14,140 \text { (at } 140 \\
\text { days) s }\end{array}$ & Shika (NGS), Nigeria & Akinola \& Olorunju [45] \\
\hline $\begin{array}{c}11,350 \text { (at } 170 \\
\text { days) s }\end{array}$ & Shika (NGS), Nigeria & Akinola \& Olorunju [45] \\
\hline $14,310(31,510) \mathrm{f}$ & Shika (NGS), Nigeria & Kallah et al. [55] \\
\hline $2,410-9,020$ (i) & Shika (NGS), Nigeria & Muhammad et al. [12] \\
\hline $4,100-10,000$ & $\begin{array}{l}\text { Zamfara reserve } \\
\text { (DSS), Nigeria }\end{array}$ & Yakubu \& Magaji [65] \\
\hline $11,070-19,600$ (i) & Kano (DSS), Nigeria & Muhammad et al. [58] \\
\hline 9,700 & Kano (DSS), Nigeria & Muhammad et al. [36] \\
\hline 3018.5 & Sokoto (DSS), Nigeria & Na-Allah [44] \\
\hline
\end{tabular}

(i) Indicates Yields Obtained Under Irrigation; k Means Cultivated Variety (Katambora); s Means Cultivated Variety (Samford); f Indicates Yields from Fresh Herbage; NGS = Nothern Guineea Savannah; DSS = Dry Sudan Savannah. 


\section{Methods of Growth and Herbage Yield Estimation}

Generally, the weight of herbage material is expressed on the dry matter basis rather than on the fresh (green) basis. This is because dry matter (DM) is a solid substance that is not subjected to daily fluctuation of its content, unlike fresh weight (FAO, 1980) [46]. reported that weight of herbage produced is one of the most important characteristics of the range plants and it is probably the best single measure of growth. Biomass is the weight of organic matter per unit area and the organic matter might include weight of new growth herbage above ground, wild animals, roots, dead organic matter or mature trees. In vegetation studies this is usually done based on unit area measurement, which is square centimeter or square meter. In measuring biomass, the herbage is clipped to constant weight in the laboratory and then weighed. The herbage biomass for the larger area is then found through multiplication $[47,48]$. Reported that there may by three general methods of estimating herbage yield; (i) the actual weight also known as clipped plot estimate (ii) the visual weight estimates or its variant weight ranking estimate and (iii) the indirect weight estimate.

The actual weight (clipped plot) estimate: This method involves the cutting of randomly selected herbage $(0-10 \mathrm{~cm}$ above ground level) within a series of sample plots or predetermined locations along transects. The cut sample is weighed immediately and saved in leveled bags for subsequent drying in order to determine the dry matter (DM) yield. Air drying can be employed to arrive at the dry matter (DM) yield should the drying facilities are not readily available. The dry matter (DM) yield obtained from various representative plots are then computed to arrive at mean dry matter yield per unit area. Total yield for the whole area (as fresh herbage or on dry matter bases) is then estimated by multiplying the mean yield per unit area by the total surface area for the pasture [48]

The visual weight (or weight-ranking) estimate: This method entails visual estimation of weights of herbage (forage) within various marked area thereby checking the estimated weights by harvesting few samples. Linear regressions of actual yield values (obtained from the few harvested samples) are thereafter fitted for calibration on the estimated values and are then transformed to estimate the actual yields by use of linear regression calibrated for each observer.

Thus, linear regression formula is shown below;

$y=a+b x$

Where; $\mathrm{y}=$ the predicted actual weight

$\mathrm{x}=$ the actual weight estimated and

$\mathrm{a}$ and $\mathrm{b}=$ regression constants.

One of the merits of this method is that it reduces the cost of labour and time involved in cutting, weighing and drying of samples.
The indirect weight estimate: This method takes into account the relationship between some

easily measured herbage (pasture) attributes which in some ways contribute to the herbage yield. Herbage attributes such as sward height, density, ground cover or their combination. The measurement of these selected herbage attributes is made from various marked areas (plots) with some plots harvested and weighed which will then be converted to yields through standards and regression analyses. The linear regression of the actual yield values (obtained from the harvested plots) on a single attribute or their combination is fitted for developing local regression equation for each type of herbage (pasture).

The local regression equation: $\mathrm{y}=\mathrm{a}+\mathrm{bx}$ is used for each type of pasture where;

$\mathrm{y}=$ the predicted actual weight

$\mathrm{x}=$ the pasture attribute or combination of attributes, and

$\mathrm{a}$ and $\mathrm{b}=$ the regression constant.

This method helps to reduce cost of labour and time associated with cutting, weighing and drying of samples before the herbage yield is determined [48]. The equipment acquired to conduct yield determinations include; sample frame called quadrat, weighing scale, marker for levelling sample bags, sickle or secateurs for harvesting the herbage, data sheet for recording immediate results (fresh weight). A field diary is also needed to record field activities and any other field observation that may assist in interpreting the results [49-54]. In addition, sample drying facility such as laboratory oven is required since results are most meaningful when reported as dry matter rather than fresh weight. (Shu'aibu, 2016) [55-62].

\section{Factors Affecting Growth and Herbage Yield}

Agro-ecological factors: According to [21], Rhodes grass (Chloris gayana) is a stoloniferous perennial grass that grows in a wide range of climates (rainfall and temperature) and soil types. Rhodes grass grows better in areas where annual rainfall is above $600 \mathrm{~mm}$ and altitude ranges from 1400 - 2400 masl. Rhodes grass grows on a wide range of soils. It grows well on well drained moderate to high fertility soils. It can also survive on infertile soils although it is unproductive and may eventually die out particularly if grazed regularly. It is not tolerant to water logging. Rhodes grass has some establishment problems on very acidic soils, but it is tolerant to saline conditions. Generally, Rhodes grass is a poor shade tolerant forage crop. Once well-established, Rhodes grass recovers well after fire due to its vigorous fibrous root system. Rhodes grass is moderately drought resistant. In addition, due to its vigorous horizontal root (stoloniferous) growth and extensive roots, Rhodes grass has great contribution in soil binding and soil erosion control [63-66]. 
Biotic factor: CASCAPE (2015) [21] reported that common pests such as armyworm (Spodoptera frugiperda) may attack Rhodes grass pasture. The following fungi have been reported on Rhodes grass: Aspergillus flavus, Cerebella andropogonis, Cladosporium sp., Claviceps sp., Cochliobolus heterostrophus, Fusarium equiseti, F. oxysporum, Helminthosporium carbonum, Himaydis sp., Nigrospora sphaerica, Puccinia chlorides, Pythium aphanidermatum, Tolyposporium chlorides, Trichoderma sp., and Uromyces kenyensis. Striga lutea and S. asiatica parasitize this plant. Nematodes isolated from Rhodesgrass include: Helicotylenchus dihystera, H. nannus, H. pseudorobustus, H. cavenessi, Hemicycliphora truncata, Hoplolaimus pararobustus, Meliodognye acronea, M. incognita acrita, M. javanica, Pratylenchus brachyurus, Rotylenchulus reniformis, Scutellonema clathricaudatum, Trichodorus minor, Tylenchus spiralis, Xiphinema elongatum, X. ifacolum. Insect pests include Fall armyworm (Spodoptera frugiperda) and caterpillars of Mocis latipes, both easily controlled by insecticides [5]. In Uganda, thrips have damaged Rhodes grass seed.

\section{Conclusion and Recommendation}

Based on the result obtained from this study, it is recommended that Rhodes grass should be cultivated with $120 \mathrm{KgNha}^{-1}$ and $30 \mathrm{~cm}$ inter row spacing in the study area.

\section{References}

1. Cook BG, Pengelly BC, Brown SD, Donnelly JL, Eagles DA, et al. (2005) Tropical Forages: an interactive selection tool, [CD-ROM], CSIRO, DPI\&F(Qld), CIAT and ILRI, Brisbane, Australia.

2. FAO (2014). Grassland Index. A searchable catalogue of grass and forage legumes. FAO, Rome, Italy.

3. Quattrocchi U (2006) CRC World dictionary of grasses: common names, scientific names, eponyms, synonyms, and etymology. CRC Press, Taylor and Francis Group, Boca Raton, USA.

4. Moore G (2006) Rhodes grass Dept Agric Food Western Australia Bull 4690 Perth.

5. James A Duke (1983) Handbook of Energy Crops.

6. Van Soest PJ (1988) Effect of environment and quality of fibre on the nutritive value of crop residues. In: Reed JD, et al. [Eds.] Plant breeding and the nutritive value of crop residues. Proceedings of a workshop held at ILCA, Addis Ababa, Ethiopia, 7-10 December 1987. ILCA (International Livestock Centre for Africa), Addis Ababa, Ethiopia. pp. 71-96.

7. Roberts BR (1987) The availability of herbage. In: Hacker JB, et al. [Eds.], The nutrition of herbivores. Academic Press, Sydney, Australia. p. 47-64.

8. Dev I (2001). Problems and prospects of forage production and utilization of Indian Himalaya. ENVIS Bulletin: Himalayan Ecology and Development 9 (2): 1-13.

9. Dzowela BH (1988) African forage plant genetic resources, evaluation of forage germplasm and extensive livestock production systems. Proceedings of the Third PANESA Workshop, Arusha, Tanzania, 2730 April 1987. ILCA (International Livestock Centre for Africa), Addis Ababa, Ethiopia. pp. 488.

10. Bamikole MA, Babayemi OJ (2004) Feeding goats with guinea grassverano stylo and nitrogen fertilized grass with energy concentrate. Archivos de Zootecina 53(201): 13-23.

11. Prakash KS (1989) Alfalfa - Present status and future considerations in Oman. International Symposium on Agriculture and Fisheries Development in Oman, Sultanate of Oman. pp. 2-5.
12. Muhammad IR, SA Abubakar (2004) Establishment and management of sown pasture. In: Gefu JA, et al. (Eds.). Forage production and management in Nigeria: A training manual. National Animal Production Research Institute (NAPRI)/ Ahmadu Bello University (A.B.U), Zaria, Nigeria. pp. 11-17.

13. De Leeuw PN, Brinckman WL (1974) Pasture and rangeland improvement in Northern Guinea and Sudan Zone of Nigeria. In: Loosli JK, et al. [Eds.] Animal Production in the Tropics. Proceedings of the International Symposium of Animal Production in the tropics, held at the University of Ibadan, Nigeria. pp. $124-151$.

14. Olubajo FO (1974) Pasture research at the University of Ibadan. In Lossli JK, et al. [Eds.] Animal Production in the Tropics. Proceedings of the International Symposium of Animal Production in the tropics, held at the University of Ibadan, Ibadan, Nigeria. pp. 67-78.

15. Rhodes I, WR Stern (1978) In Plant relations in pastures. (JR Wilson, et al. [Eds.]) CSIRO, East Melbourne, Australia. pp. 175-189.

16. Keftasa D (1996) Effect of management on Rhodes grass and Lucerne pastures with special references to developmental stages at cutting and associated changes in nutritional quality.

17. Trivedi BK (2010) Grasses and Legumes for Tropical Pasture. Indian Agricultural Research Institute, India.

18. Ecocrop (2014) Ecocrop database. FAO, Rome, Italy.

19. (2008) ESGPIP (Ethiopia Sheep and Goat Productivity Improvement Program). Technical Bulletin No. 17. Fodder Establishment, Management and Utilization Techniques for the smallholder.

20. Fekede F (2000) Natural pasture management, feed production and utilization techniques. ESAP (Ethiopian Society of Animal Production), Addis Ababa, Ethiopia.

21. (2015) CASCAPE (Capacity building for Scaling up of evidence-based practices in Agricultural Production in Ethiopia).

22. HARC (Holetta Agricultural Research Center) (2004) Feed Resources Development and Utilization: Possible Options and Recommendations Under Ethiopia Condition.

23. Onyeonagu CC (2005) Reclamation of a run-down pasture through improved management. Thesis submitted to the Faculty of Agriculture University of Nigeria. p. 65.

24. Peake DCI, Myers RJK, Henzell EF (1990) Sown pasture production in relation to nitrogen fertilizer and rainfall in Southern Queensland. Tropical Grasslands 24: 291-298.

25. Brunet E, Avila A, Rios C, Almaguer J (1990) Response of four irrigated pasture grasses to $\mathrm{N}$-applications. Environmental Science 13(1): 43-52.

26. Edokwe RE (1991) Influence of guinea grass density, undersowing date and $\mathrm{N}$ fertilizer on the performance of guinea grass-maize mixture. BSc Project Report submitted to the faculty of Agriculture University of Nigeria, Nsukka. p. 51

27. Okeagu MU (1991) The Agronomy of newly introduced grass pastures in the northern Guinea Savanna Zone of Nigeria. 3. Panicum maximum (Jacq). World Review of animal production, Italy 26(1): 87-90.

28. Keftasa D (1990) Effect of Management Practices on Rhodes Grass and Lucerne Pasture with Especial References to Development Stage at Cutting and Associated Change in Nutritional Quality. Institute of Agriculture Research, Kulumsa Research Center, Ethiopia.

29. Abdel Rahman FI (2007) Effect of Seed Rate and NPK Fertilization on Growth and Yield Forage Quality of Rhodes Grass (Chloris gayana L. Kunth). Faculty of Agriculture, University of Khartoum, Sudan.

30. Anonymous (2006) Fertilizer Use by Crops. Food and Agriculture Organization of the United Nations.

31. Borhan H, Hago TE (2000) Principle of Crop Production. University of Khartoum Printing Press, Sudan.

32. Saad HH, (2010) Evaluation of Nitrogen Fertilizers on Quality and Quantity of Rhodes Grass (Chloris gayana L Kunth). MSc Thesis. Faculty 
of Agriculture Studies, Sudan University of Science and Technology, Sudan.

33. Arshad I, Medani KM, Khan ZA (2014) Effect of Manual and Artificial Application of NPK Fertilizers on the Growth and Yield of Rhodes Grass (Chloris Gayana L. Kunth.) by Using Central Pivot Irrigation Technology. International Journal of Research 1(7): 824-838.

34. Qamar IA, Akbar G, M Asif (2000) Performance of summer grasses in arid rangelands of Dhabiji (Sindh). Sci Technol Develop 19: 45-47.

35. Yossif AM, Ibrahim YM (2013) "Effect of Fertilizers (Urea, Farmyard and Chicken Manure) on Growth and Yield of Rhodes Grass (Chloris Gayana L. Knuth.)". Universal Journal of Plant Science 1(3): 85-90.

36. Mohammed HM (2009) Pasture in Sudan ways of support and development. Paper presented in the conference Role of Ranchers in the Development of Pastoral Sector. Jeddah, Saudi Arabia.

37. Michael J Ssali (2016) Accessed at: http://www.monitor.co.ug/ Magazines/Farming/ What-is-crop-spacing-/689860-31979682jswg9z/index.html. Retrieved on: 17th May 2017.

38. EARO (Ethiopian Agricultural Research Organization) (2004). Directory of released crop varieties and their management. Addis Ababa, Ethiopia.

39. Ishiaku YM, Hassan MR, Tanko RJ, Amodu JT, Abdu SB, et al. (2016) Effect of plant spacing on yield and quality of Columbus grass (Sorghum almum) under rain fed in Shika, Zaria, Nigeria. Journal of Animal production Research 28(1): 318-328.

40. Malami BS, M Sama'ila (2011) Effects of inter and intra row spacing on growth characteristics and fodder yield of cowpea (Vigna unguiculata(L.) Walp. Var. Kanannado) in the semi-arid north-western Nigeria. Department of Animal Science, Faculty of Agriculture, Usmanu Danfodiyo University, Sokoto. Nigerian Journal of Basic and Applied Science 20(2): 125-129.

41. Duke JA (1997) Rhodes grass (Chloris gayana Kunth) In: Handbook of Energy Crops (Unpublished). Centre for New Crops and Plant Products, Purdue University.

42. FAO (2009) Rhodes grass (Chloris gayana Kunth). Food and Agricultural Organization of the United Nations (FAO).

43. Yesihak K (2008) Effect of seed proportion of Rhodes grass (Chloris gayana Kunth) andWhite seed clover (Melilotus alba) at sowing on agronomic characteristics and nutritional quality. Livestock Research for Rural Development.

44. Na Allah, Yakubu (2015) Comparative evaluation of productivity of native and introduced forage grasses and legumes in the semi-arid zone of Nigeria. A PhD thesis submitted to the postgraduate school, Usmanu Danfodiyo University, Sokoto, Nigeria.

45. Akinola JO, Olorunju SAS (1990) Changes in herbage yield and quality of indeginoust and introduced forage species with age. Journal Animal Production Research 10(1): 1-20.

46. Pratt DJ, Gwynne MO (1977) Rangeland Management and Ecology in East Africa. Hodder and Stoughten Educational, Great Britain, UK, pp. 391.

47. Tesfaye, Desalew (2008) Assessment of feed resources and rangeland condition in metema district of north gondar zone, Ethiopia. M. Sc. thesis Submitted to the Department of Animal Sciences, School of Graduate Studies, HARAMAYA UNIVERSITY, Ethiopia.

48. Kallah MS (2004) Rangeland in Nigeria: A partial resource appraisal.

49. Ahmad A (2016) Effect of nitrogen fertilizer levels and inter-row spacing on growth and herbage yield of Columbus grass (Sorghum almum parodi) pasture in semi-arid zone of Sokoto, Nigeria. A project report submitted to the Department of Animal Science, Faculty of Agriculture, Usmanu Danfodiyo University, Sokoto, Nigeria, p. 87.
50. Aregheore OM (2009) Country pastures or forage resource profiles, Nigeria.

51. Bell A (1991) Plant Form. Oxford, Oxford University Press, UK. pp. 182.

52. Brady NC (1974) The nature and properties of soils. ( $8^{\text {th }}$ edn), Macmillan Publishing Co, New York. USA. pp. 125.

53. Jones DIH, Wilson A (1987) Nutritive quality of forages. In: Hacker JB, et al. (Eds.), The nutrition of herbivores. Academic Prr-ss, Sydney, Australia, p. 65-90.

54. Kallah MS, Mzamane N (1984) The productivity of pasture cropsunder irrigation in the dry Sudan savannah. Paper presented to the 1984 irrigation cropping scheme. IAR/ABU, Samaru, Zaria, Nigeria, p. 8.

55. Kallah MS, Muhammad IR, Baba M, Lawal R (1999) The effect of maturity on composition of hay and silage made from Columbus grass (Sorghum almum). Tropical grasslands 33: 56-59.

56. Mamman AB, Oyebanji JO, Peter SW (2000) Nigeria a people united a future assured (survey of states). Volume 2, Gabumo Publishing company Ltd, Calabar, Nigeria.

57. Muhammad A, Dikko AU, Audu M, A Singh (2010) Comparative effects of cowpea and soybean genotypes on N2- fixation and N-balance in Sokoto dry sub-humid Agro-ecological zone of Nigeria. Nigerian Journal of Basic and Applied Science 18(2): 297-303.

58. Muhammad IR, Abdullahi B, Mohammed AK, Tanko RJ, Kallah MS, et al. (2005) Influence of irrigation intervals on dry matter yield, concentration of crude protein, calcium and phosphorus in Lablab purpureus and Sorghum almum fodder in the Sudan savannah zone of Nigeria. Nigeria Journal of Animal Production 32 (2): 280-286.

59. Muhammad IR, Mustapha A, Mohammed B, Abdurrahman LS, Ahmad MY (2009) Commercially focused forage production from Columbus grass and Centurion grown alone or in mixtures in the semi-arid environment. Agricultural Journal 4 (2):91-95.

60. NSWDPI (2004) Rhodes grass. New South Wales Department of Primary Industries, $3^{\text {rd }}$ Edition.

61. Oloyo RA, Ilelaboye NOA (2002) Nutritive quality evaluation of seeds of some lesser known crops. Journal of Animal Production Research 18 $(1 \& 2): 11-18$

62. Sakaba YB (2011) A detailed oil survey of Usmanu Danfodiyo University Dabagi Farm, Sokoto, Nigeria. An M.Sc. Dissertation (unpublished), Department of Soil Science and Agricultural Engineering. Faculty of Agriculture, Usmanu Danfodiyo University, Sokoto, Nigeria, p. 98.

63. Tewodros M, Moseret M, Tesfaye Y (2012) Assessment of Alfalfa (Medicago Sativa) and Rhodes (Chloris gayana) at Saddo Kedidaganila district of southern Ethiopia. Journal of Natural Science Research 2(9): 30-35.

64. Umunna NN, PA Iji (1993) The natural feed resources in Nigeria. In: Adamu AM, et al. [Eds.] Forage Production and Utilization in Nigeria. Proceedings of National Workshop held in Kaduna, Nigeria by the National Livestock Project Division (NLPD), Kaduna, Federal Ministry of Agriculture and Natural Resources, Nigeria. pp.16-31.

65. Yakubu AI, Magaji MD (2004) Evaluation of productivity of some grass pasture species in Zamfara grazing reserve. In: Tukur H, M, et al. (Eds.) Sustainable Livestock Production Under Changing Economic fortunes. Proceedings of the 29th NSAP Annual conference; held 21-25 March 2004 at Usmanu Danfodiyo University, Sokoto, Nigeria. pp. 318-321.

66. Yayock JY, JJ Owonubi (1986) Weather-sensitive agricultural operations in groundnut production: The Nigerian situation. ICRISAT Sahelian Centre, Niamey, Nigeria, pp. 213-226. 